\title{
Nutrition value and viscosity of polymeric enteral nutrition products based on purple sweet potato flour with variation of maltodextrin levels
}

\author{
Rusdin Rauf*, Anggraeni Utami
}

\section{ABSTRACT}

Background: One obstacle in commercial enteral food formulation is the adjustment between nutritional value and rheological characteristics of the product.

Objectives: To evaluate the nutritional value and viscosity of polymeric enteral nutrition (PEN) products made from purple sweet potato flour with variations in the level of maltodextrin as a stabilizer.

Methods: The completely randomized design was used with four variations of maltodextrin, which was $2.5 \%, 5 \%, 7.5 \%$, and $10 \%$. The research was carried out by making purple sweet potato flour, then its proximate composition was measured as a basis for formulating a PEN product that was $200 \mathrm{kcal} / 200 \mathrm{~mL}$, with $60 \%$ carbohydrates $(120 \mathrm{kcal} / 200 \mathrm{~mL}), 15 \%$ protein $(30$ $\mathrm{kcal})$, and $25 \%$ fat (50 kcal). The proximate composition and calorie value of the PEN products were tested. The PEN products were added hot water at a temperature of $90^{\circ} \mathrm{C}$; then, the viscosity was measured at room temperature. The viscosity of two types of commercial enteral nutrition products was measured as a reference.

Results: The results showed that there was an effect of maltodextrin level on moisture, fat, and protein contents of PEN products, but there was no effect on calorie values. The viscosity of the PEN products displayed that the higher the maltodextrin level, the higher the viscosity of the product. The viscosity of the PEN products in accordance with the commercial enteral products was the treatment of maltodextrin $5 \%$ and $7.5 \%$.

Conclusion: There is an effect of maltodextrin as a stabilizer on the nutritional value and viscosity of PEN products based on purple sweet potato flour.

Keywords: enteral; nutrition value; purple sweet potato; viscosity

\section{INTRODUCTION}

Everyone must meet the needs of nutrients for a healthy life obtained through food intake. However, in hospitals, there are often patients who have difficulties or are unable to meet their food intake needs orally so that malnutrition occurs. ${ }^{1,2}$ The patient causes this has a particular condition such as severe burns, post-surgery / surgery, stroke, kidney disease, cirrhosis of the liver, and other diseases. Besides, various reports show high cases of malnutrition for patients in hospitals, including $22 \%$ in South Korea, China, $72.8 \%$, India 27.6\%, Malaysia $21 \%$, and Indonesia $34.8 \%$ to $37.1 \%$.,

Enteral nutrition is an attempt to overcome the problem. The enteral food is a liquid food and liquified flour, which is inserted through the tube into the gastrointestinal pathway, which is intended for patients who cannot consume food orally. ${ }^{5}$ Enteral food can be given to individuals who have malnutrition problems and who want to maintain their nutritional status in good condition. ${ }^{6}$

Based on its availability, enteral food consists of two types, namely liquid or home-made and in the form of flour or commercial. ${ }^{7}$ Liquid or blenderized enteral foods are made from ordinary foods that are blended and liquified. ${ }^{6}$ Flour type enteral foods that are ready to be liquified are called commercial enteral foods, with varying nutritional values as needed, are practically prepared, and are not easily contaminated. ${ }^{7}$

Currently, various commercial enteral food products have been widely marketed, but commercial enteral food is only to meet the needs of nutrients. In general, the food produced should consider not only the adequacy of nutrients and physical standard ${ }^{8,9}$, but also the psychosocial factors associated with the use of local food, such as cassava, corn, nuts, fruits, and vegetables. ${ }^{10}$ One of the local foodstuffs in Indonesia that has the potential to be developed as an enteral food raw material is the purple sweet potato.

Purple sweet potato has been widely known as a food that has many health benefits. The purple sweet potatoes indicated the anti-inflammatory and anti-cancer effects. ${ }^{11}$ The inhibitory effect of colorectal cancer from purple sweet potato extract through apoptotic mechanisms. ${ }^{12}$ Even reported that purple sweet potato extract has antioxidant activity and has a hypoglycemic effect. ${ }^{13}$ The purple sweet potato extract could reduce blood glucose levels of rats given high glucose. ${ }^{14}$ Purple sweet potato extract increased glycemic control in type 2 diabetes patients ${ }^{15}$, and blood pressure in hypertensive elderly patients. ${ }^{16}$

The use of purple sweet potato flour as a raw material for enteral food products presents a particular obstacle to the product's rheological stability due to its

Nutrition Science Department, Faculty of Health Science, Universitas Muhammadiyah Surakarta. Jl. Ahmad Yani, Kartasura, Surakarta, Jawa Tengah 57169,

Indonesia.

${ }^{*}$ Corresponding author : E-mail: rusdin.rauf@ums.ac.id 
high starch content. An attempt to overcome this problem is to add a stabilizer, such as maltodextrin. Maltodextrin is a modified product of starch which has a high solubility in cold water so that it is appropriate to be used as a stabilizer in enteral nutrition products. The use of these stabilizers can have an impact on the nutritional value and viscosity of enteral products. Preliminary research displayed that the use of maltodextrin in PEN products from PSP (purple sweet potato) flour following the viscosity of commercial PEN products, which was between $2.5 \%$ to $10 \%$.

To the best of our knowledge, studies related to nutrition value and viscosity of polymeric enteral nutrition products based on purple sweet potato flour are still rare. Moreover, the research can be used as a reference in formulating enteral foods specifically for nutritionists. The purpose of this study was to evaluate the effect of maltodextrin on nutritional value and viscosity of PEN products based on purple sweet potato flour.

\section{MATERIALS AND METHODS}

\section{Materials}

The ingredients used in this study were PSP flour, maltodextrin, soy protein isolate, sugar, and vegetable oil. The PSP was obtained from a farmer in Ngawi Regency, Central Java Province, Indonesia. Maltodextrin, sugar, and vegetable oil were obtained from supermarkets in Surakarta. Isolated Soy Protein (ISP) was purchased from a chemical distribution company in Jakarta.

\section{Purple Sweet Potato Flour Making}

The manufacture of PSP flour was modified from the procedure of Rauf et al. (2018). ${ }^{17}$ PSP is washed with running water then peeled. PSP thinly sliced with a thickness of $\pm 2 \mathrm{~mm}$. PSP slices were then dried using sunlight for \pm 24 hours, then milled and sieved using 80 mesh. The PSP flour was made in the Food Science Laboratory, Universitas Muhammadiyah Surakarta.

\section{Formulation of Enteral Nutrition}

The PSP flour and ISP were measured for moisture, ash, fat, and protein contents, as well as calorie values. The nutritional values and calories were used as a reference to calculate the needs of each ingredient with the calorie value of each nutrient specified, namely carbohydrates $60 \%$ (120 kcal.), protein 15\% (30 kcal.) and fat $25 \%$ (50 kcal.) from total calorie (200 kcal.). The formula was based on the recommendation of ASPEN (American Society for Parenteral and Enteral Nutrition). ${ }^{18}$

The calorie values of carbohydrates, proteins, and fats from raw materials were calculated. Furthermore, the need for each ingredient was determined using the two until five variables Algebra equation, as follow: ${ }^{19}$ Eq-1

where:

$$
\begin{aligned}
& \mathrm{A}=\text { PSP flour }(\%) \\
& \mathrm{B}=\text { Isolated soy protein }(\%) \\
& \mathrm{W}=\text { weight of enteral product } \\
& \mathrm{Cp}=\text { calorie of protein }(\mathrm{kcal} / \mathrm{g})
\end{aligned}
$$

On the eq-1, total protein as much as $30 \mathrm{kcal}$ was a constant. W was also a constant that must be estimated in advance how many grams of product for $200 \mathrm{kcal}$. In this study, it was estimated that $50 \mathrm{~g}$ of the product. Only ingredients of $\mathrm{A}$ and $\mathrm{B}$ consist of the protein of five ingredients used so that in the eq-1, only two variables were included.

The variable A was also used as a constant by estimating the percentage of PSP flour needed from the total weight of the product. After the estimation value, it could be calculated how many grams of variable B (ISP needed with variable A to meet $30 \mathrm{kcal}$ of protein from the product).

$\left(A x W_{x} C p\right)+\left(B x W_{x} C p\right)+\left(D_{x} W_{x} C f\right)=50 \mathrm{kcal}$ fat $\ldots \ldots \ldots . . . \mathrm{Eq}-2$

where:

$$
\begin{aligned}
& \text { A }=\text { PSP flour }(\%) \\
& \text { B }=\text { Isolated soy protein }(\%) \\
& \text { D = Vegetable oil }(\%) \\
& \text { W = weight of enteral product } \\
& \text { Cf }=\text { calorie of fat }(\mathrm{kcal} / \mathrm{g})
\end{aligned}
$$

On the eq-2, ingredients that consist of fat calories could be used as variables, including $\mathrm{A}, \mathrm{B}$, and $\mathrm{D}$. The values of variables $A$ and $B$ were known from eq-1 so that the weight of the variable $\mathrm{D}$ from the vegetable oil could be determined.

\section{$\left(A_{x} W_{x} C p\right)+\left(B_{x} W_{x} C p\right)+\left(C_{x} W_{x} C f\right)+\left(D_{x} W_{x} C f\right)+E_{x} W_{x} C f=$ 120 kcal carbohydrate ............. Eq-3}

Where:

$$
\begin{aligned}
& \text { A }=\text { PSP flour }(\%) \\
& \text { B }=\text { Isolated soy protein }(\%) \\
& \text { C }=\text { Maltodextrin }(\%) \\
& \text { D = Vegetable oil }(\%) \\
& \text { E }=\text { Sugar }(\%) \\
& \mathrm{W}=\text { weight of enteral product } \\
& \mathrm{Cc}=\text { calorie of carbohydrate }(\mathrm{kcal} / \mathrm{g}) \\
& \mathrm{Cp}=\text { calorie of protein }(\mathrm{kcal} / \mathrm{g}) \\
& \mathrm{Cf}=\text { calorie of fat }(\mathrm{kcal} / \mathrm{g})
\end{aligned}
$$

The values of variables $\mathrm{A}, \mathrm{B}$, and $\mathrm{D}$ have been determined from the Eq-1 and eq-2. The value of Variable C (maltodextrin) could also be determined, because it was a treatment in this study. The eq-3 was only applied to calculate the sugar requirement (Variable 
E) to complete the total calorie value of carbohydrates, which was $120 \mathrm{kcal}$.

Table 1. Formula for the PEN Products

\begin{tabular}{lcccc}
\hline \multirow{2}{*}{ Ingredients } & \multicolumn{4}{c}{ Maltodextrin } \\
\cline { 2 - 5 } & $\mathbf{2 . 5 \%}$ & $\mathbf{5 \%}$ & $\mathbf{7 . 5 \%}$ & $\mathbf{1 0 \%}$ \\
\hline Maltodextrin (g) & 1.25 & 2.50 & 3.75 & 5.00 \\
PSP flour (g) & 29.60 & 29.60 & 29.60 & 29.60 \\
ISP (g) & 8.90 & 8.90 & 8.90 & 8.90 \\
Vegetable oil (g) & 5.55 & 5.55 & 5.55 & 5.55 \\
Sugar (g) & 3.75 & 2.50 & 1.25 & 0 \\
Calorie (kcal) & 200 & 200 & 200 & 200 \\
Netto (g) & 49.05 & 49.05 & 49.05 & 49.05 \\
\hline
\end{tabular}

All ingredients were weighed and then mixed. PEN products were packaged using aluminum foil and stored in the refrigerator at $4^{\circ} \mathrm{C}$ until further analyzed.

\section{Nutrition Value and Calorie Measurements}

The nutrition value of enteral nutrition products evaluated was moisture, ash, fat, and protein contents. Moisture content was calculated using thermogravimetry, ash content using the dry method, fat using Soxhlet extraction, and protein using microKjeldahl. ${ }^{20}$ The nutrition value was conducted in the laboratory of food chemistry and biochemistry, Faculty of Agricultural Technology, Universitas Gadjah Mada.

The calorie value was tested in the Center for Food and Nutrition, Universitas Gadjah Mada, using a Bomb calorimeter. A 1 gram sample was put into the sample cup. The sample cup was placed in a Vessel Bomb calorimeter. A total of $1 \mathrm{~mL}$ of distilled water was included in the Calorimeter Bomb Vessel. Oxygen gas flows into the vessel as much as $30 \mathrm{~atm}$; then, the vessel was put into the reactor. A bomb calorimeter was connected to an electric current to start the combustion process.

\section{Viscosity Test}

The viscosity measurement was conducted in the Food Science Laboratory, Universitas Muhammadiyah Surakarta, using a Brookfield DV-II + Pro viscometer with spindle no. 62 , a rotation speed of $60 \mathrm{rpm}$ following the procedures of Rauf and Sarbini (2012) and Stroud et al. (2003). ${ }^{21,22}$ The product was put into a glass, then brewed with hot water at a temperature of $90{ }^{\circ} \mathrm{C}$ to a volume of $200 \mathrm{~mL}$, stirred for 20 seconds. The sample was cooled to $27{ }^{\circ} \mathrm{C}$. Viscosity data were taken every 10 seconds for 1 minute.

\section{Data Analysis}

This study used a completely randomized design with four variations of the concentration of maltodextrin, namely $2.5 \%, 5 \%, 7.5 \%$, and $10 \%$ of total calorie. Each sample was analyzed three times for each quality indicator. The same treatment of samples was subsequently measured in triplicate. As a comparison of viscosity, two types of commercial enteral products were used. Data that not normally distributed were analyzed using Kruskal-Wallis, while those that normally distributed were analyzed using One Way Anova, followed by Duncan's at the 0.05 level.

\section{RESULTS}

\section{Nutrition Value and Calorie}

The results on nutrition values of PSP flour, especially for moisture, ash, fat, and carbohydrate levels, showed conformity with the standards proposed by Ambarsari (2009). ${ }^{23}$ For ISP, the water content was following the provisions of codex general standard 1751989, while the protein content did not meet the standard. ${ }^{15}$ The nutrition value and calorie of PSP flour and ISP is displayed in Table 2.

Table 2. Nutrition Value and Calorie of PSP Flour and ISP

\begin{tabular}{lll}
\hline Nutrition & PSP Flour & ISP \\
\hline Moisture (\%) & $7.12 \pm 0.01$ & $4.12 \pm 0.02$ \\
Ash $(\%)$ & $2.75 \pm 0.03$ & $1.03 \pm 0.03$ \\
Protein $(\%)$ & $1.7 \pm 0.01$ & $89.96 \pm 0.12$ \\
Fat & $0.03 \pm 0.01$ & $2.75 \pm 0.07$ \\
Crude fiber $(\%)$ & $1.18 \pm 0.09$ & - \\
Carbohydrate $(\%$ by diff.) & 89.86 & 2.17 \\
Calorie (kcal.) & $338.15 \pm 0.35$ & $338.02 \pm 0.12$ \\
\hline
\end{tabular}

The nutrition value of PEN products, in general, was affected by the variation of maltodextrin levels. The more the maltodextrin level, the more the moisture, fat, and the calorie levels of PEN products. Although the nutritional value of PEN products was statistically significant, the difference in the nutritional value of each treatment was small. The treatment of $10 \%$ maltodextrin of PEN product indicated the highest moisture level, which was $7.19 \%$. The highest fat level demonstrated by PEN product with the treatment of maltodextrin 10\%, which was $11.66 \%$ of total calorie. The most significant calorie of PEN product was given by a $10 \%$ maltodextrin that was not significantly different from the $7.5 \%$ maltodextrin statistically. The nutrition value and calorie of PEN products are given in Table 3.

The PEN products for the treatments of $2.5 \%, 5 \%$, and $7.5 \%$ maltodextrin revealed that there was no difference for the crude protein levels. The $10 \%$ of maltodextrin of PEN products indicated the highest crude protein. On the other side, the treatments of $2.5 \%$, $5 \%$, and $7.5 \%$ maltodextrin displayed no significant difference for protein level. 
Table 3. Nutrition Value and Calorie of PEN Products

\begin{tabular}{ccccc}
\hline Ingredients & \multicolumn{3}{c}{ Maltodextrin } \\
\cline { 2 - 5 } & $\mathbf{2 . 5 \%}$ & $\mathbf{5 \%}$ & $\mathbf{7 . 5 \%}$ & $\mathbf{1 0 \%}$ \\
\hline Moisture (\%) & $6.74 \pm 0.11^{\mathrm{a}}$ & $6.89 \pm 0.44^{\mathrm{ab}}$ & $7.03 \pm 0.29^{\mathrm{ab}}$ & $7.19 \pm 0.35^{\mathrm{b}}$ \\
Ash (\%) & $2.37 \pm 0.04^{\mathrm{b}}$ & $2.46 \pm 0.15^{\mathrm{b}}$ & $2.26 \pm 0.08^{\mathrm{a}}$ & $2.27 \pm 0.07^{\mathrm{a}}$ \\
Protein (\%) & $15.35 \pm 0.14^{\mathrm{a}}$ & $15.38 \pm 0.24^{\mathrm{a}}$ & $15.43 \pm 0.19^{\mathrm{a}}$ & $15.74 \pm 0.33^{\mathrm{b}}$ \\
Fat (\%) & $11.27 \pm 0.13^{\mathrm{a}}$ & $11.46 \pm 0.26^{\mathrm{ab}}$ & $11.50 \pm 0.34^{\mathrm{ab}}$ & $11.66 \pm 0.33^{\mathrm{b}}$ \\
Carbohyd. (by diff.) & $64.10^{\mathrm{b}}$ & 63.79 & 63.73 & 63.24 \\
Calorie (kcal) & $198.4 \pm 0.5^{\mathrm{a}}$ & $198.43 \pm 1.1^{\mathrm{a}}$ & $199.27 \pm 0.7^{\mathrm{b}}$ & $199.33 \pm 0.7^{\mathrm{b}}$ \\
\hline Different
\end{tabular}

Different letters represent significant differences $(p \leq 0.05)$.

\section{Viscosity}

The results demonstrated that there was an effect of maltodextrin levels on the viscosity of the PEN products. The more the maltodextrin level, the more the viscosity of the PEN products. The highest viscosity of the PEN product was shown by the treatment of $10 \%$ maltodextrin, whereas the treatment of $2.5 \%$ maltodextrin indicated the lower viscosity of the PEN product.

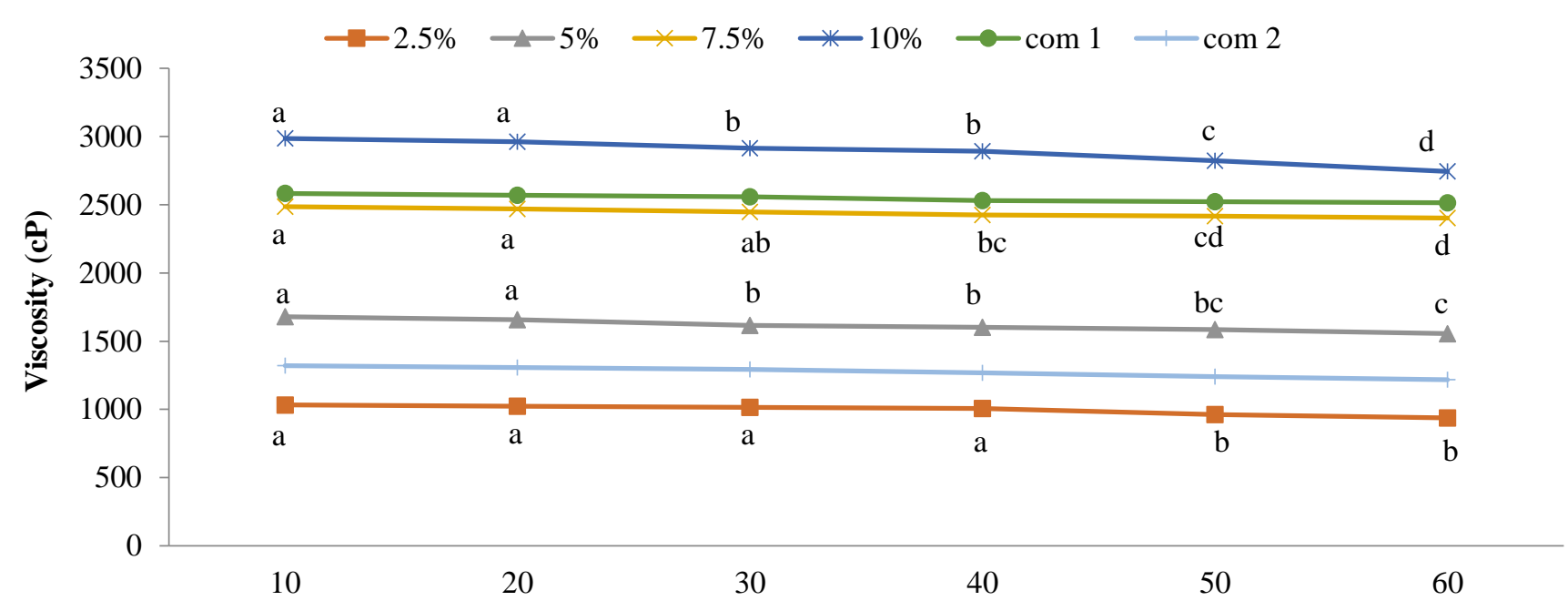

Different letters represent significant differences $(p \leq 0.05)$.

Shear time (Sec.)

Figure 1. Viscosity of PEN Products with the Variation of Maltodextrin Levels.

The viscosity of PEN products during measurement every 10 seconds has decreased significantly. The higher the initial viscosity of a PEN product, the more significant the decrease in viscosity during shear-time. The most considerable decrease in viscosity occurred in PEN products with $10 \%$ maltodextrin treatment, whereas the lowest was $2.5 \%$ maltodextrin treatment.

\section{DISCUSSION}

The results of the nutritional value of PSP flour showed the suitability of the proximate composition with the recommendations for Indonesian National Standard, except for proteins with a minimum standard of $3 \% .^{23}$ Although the protein from PSP flour used in this study was lower than the recommended standard. Low protein levels in PSP flour could be caused by planting location, temperature, and climate factors. ${ }^{25,26}$

The primary indicator of ISP products is protein content. The ISP has a high protein content that is $85 \%$ to $96 \%$, so it can be used to increase the nutritional value of food products. ${ }^{27,}{ }^{28}$ The protein content used in this study was $89.96 \%$.

The nutrition value of PEN products that need to be modified is moisture content, which was $6.74 \%$ $7.19 \%$. There is no standard of moisture content for the commercial enteral formulas. These results meet the criteria if using a standard flour in general, which is less than $10 \%$. However, the water content of PEN products still needs to be reduced if using the standard of formula milk, which is less than 5\%, then. The moisture content of PEN products was mostly from PSP flour. The moisture content of PEN products can be reduced by lowering the moisture content of PSP flour. 
Nutrition value and viscosity of polymeric enteral nutrition products based on purple sweet potato flour ...

Table 4. The Nutrition Calorie of PEN Products

\begin{tabular}{lccccc}
\hline \multirow{2}{*}{ Ingredients } & \multirow{2}{*}{ Predicted } & \multicolumn{4}{c}{ Maltodextrin } \\
\cline { 3 - 6 } & & $\mathbf{2 . 5 \%}$ & $\mathbf{5 \%}$ & $\mathbf{7 . 5 \%}$ & $\mathbf{1 0 \%}$ \\
\hline Protein (kcal.) & 30 & 30.12 & 30.18 & 30.27 & 30.88 \\
Fat (kcal.) & 50 & 49.75 & 50.59 & 50.77 & 51.47 \\
Carbohyd. by diff. (kcal.) & 120 & 118.53 & 117.66 & 118.23 & 116.98 \\
\hline Total calories (kcal.) & 200 & 198.4 & 198.43 & 199.27 & 199.33 \\
\hline
\end{tabular}

The nutrition value of PEN products in Table 3 can be converted into calorie value, which is given in Table 4. The calorie was in accordance with the results of the analysis of the PEN product nutrition value. The macronutrient calories of PEN products complied with the standards recommended by ASPEN as well as ESPEN (European Society for Parenteral and Enteral Nutrition), which are $15 \%$ to $25 \%$ protein or equivalent to 30 kilocalories to 50 kilocalories. Furthermore, for fat, which is $25 \%$ to $40 \%$ or equal to 50 kilocalories until 80 kilocalories. The maximum calorie for carbohydrates is $60 \%$ or the equivalent to 120 kilocalories. ${ }^{18,} 29$ The nutritional calorie of the commercial PEN product indicated the protein, fat, and carbohydrate contents, which was $15 \%, 30 \%$, and $55 \%$, respectively or equivalent to 30 kilocalories, 60 kilocalories, and 110 kilocalories. ${ }^{30}$ The fat content of the commercial PEN product was higher than the PEN product of this research, as well as ASPEN and ESPEN recommendations.

The results displayed that during the shear process through measurement, there was a significant decrease in viscosity for all PEN products. These PEN products provide a non-Newtonian type of viscosity. NonNewtonian viscosity is the viscosity of a liquid that changes in friction between surfaces and the liquid wall. $^{31}$

The viscosity of PEN products was not only affected by shear time but also the level of maltodextrin. The higher the level of maltodextrin used, the higher the viscosity. The lowest viscosity was shown by the treatment of maltodextrin $2.5 \%$ with initial viscosity of $1,032.9 \mathrm{cP}$ and final viscosity of $937.6 \mathrm{cP}$. In contrast, the highest viscosity was given by maltodextrin $10 \%$ treatment with initial viscosity of $2,985.5 \mathrm{cP}$ and final viscosity of 2,744 cP. Various commercial enteral formulas displayed a various range of viscosity such as $800 \mathrm{cP}$ to $13,000 \mathrm{cP}, 900 \mathrm{cP}$ to $12,000 \mathrm{cP}, 1,000 \mathrm{cP}$ to $10,000 \mathrm{cP}$, and $2,000 \mathrm{cP}$ to $10,000 \mathrm{cP}{ }^{32}$ One of the factors that affect the viscosity of enteral nutrition products is thickener or stabilizer. ${ }^{9}$ The more the level of thickener, the higher the viscosity of the PEN products. The higher the addition of maltodextrin concentrations, the higher the viscosity of pasta and gel of products. ${ }^{33}$

The viscosity of PEN products is still following the viscosity of commercial enteral formula products, both commercial products with low viscosity and high viscosity. There are two maltodextrin treatments whose viscosity is between the two commercial products, namely $5 \%$ and $7.5 \%$. Viscosity is critical to consider in choosing a product because the viscosity can have a clinical impact on patients. ${ }^{34}$

\section{CONCLUSION}

Enteral food products derived from variations in raw materials can be designed for nutritional value and calorie by using the Algebra equation, including PSP flour. The use of maltodextrin can increase the viscosity of PEN products based on PSP products. PEN products provide a type of non-Newtonian viscosity with the characteristic of a decrease in viscosity during the shear process. Based on the nutrition and calorie values, as well as the viscosity, all formulas in the research meet the requirements compared to the ASPEN and ESPEN standards as well as commercial PEN products.

\section{ACKNOWLEDGEMENT}

The authors would like to thanks the Universitas Muhammadiyah Surakarta, which has provided financial support for this research.

\section{REFERENCES}

1. Khan MN, Farooq S, Khalid S, Kausar N, Khalid M. Development of energy dense cost-effective homemade enteral feed for nasogastric feeding. IOSR Journal of Nursing and Health Science. 2015;4(3):34-41.

2. Poongodi VT, Deepa M. Optimization of natural polymeric enteral feed formula using response surface methodology. Asian Journal of Science and Technology. 2010;2:39-43.

3. Kang MC, Kim JH, Ryu SW, Moon JY, Park JH, Park JK, et al. Prevalence of malnutrition in hospitalized patients: a multicenter cross-sectional study. J Korean Med Sci. 2018;33(2):1-10. https://doi.org/10.3346/jkms.2018.33.e10

4. Chern CJH, Lee S-D. Malnutrition in hospitalized Asian seniors: An issue that calls for action. Journal of Clinical Gerontology \& Geriatrics. 2015;6:73-7. https://doi.org/10.1016/j.jcgg.2015.02.007

5. Nilesh MR, Vilas PA, Ambadas JS, Sharadchandra MN. Formulation development of enteral nutrition products. Int Res J Pharm. 2011;2(3):19-28. 
6. Sousa LRM, Ferreira SMR, Schieferdecker MEM. Physicochemical and nutricional characteristics of handmade enteral diets. Nutricion Hospitalaria. 2014;29(3):568-74.

https://doi.org/10.3305/nh.2014.29.3.7083

7. Vieira MMC, Santos VFN, Bottoni A, Morais TB. Nutritional and microbiological of commercial and homemade blenderized whole food enteral diets for home-based enteral nutritional therapy in adults. Clin Nutr.

2016;xxx:1-5. https://doi.org/10.1016/j.clnu.2016.11.020

8. Cases-Augustench P, Salas-Salvado P. Viscosity and flow-rate of three high-energy, high fibre enteral nutrition formulas. Nutricion Hospitalaria. 2009;24(4):492-7.

9. Wakita M, Masui H, Ichimaru S, Amagai $\mathrm{T}$. Determinant factors of the viscosity of enteral formulas: basic analysis of thickened enteral formulas. Nutr Clin Pract. 2012;27(1):82-90. https://doi.org/10.1177/0884533611427146

10. Viani K. Parenteral and enteral nutrition for pediatric oncology in low- and middle-income countries. Indian J Cancer. 2015;52:182-4.

11. Sugata M, Lin C, Shih Y. Anti-inflammatory and anticancer activities of Taiwanese purple sweet potatoes (Ipomea batatas L. Lam) extracts. Biomed Res Int. 2015;1-10. https://doi.org/10.1155/2015/768093

12. Lim S, Xu J, Kim J, Chen T, Su X, Standard J, et al. Role of anthocyanin-enriched purple-fleshed sweet potato P40 in colorectal cancer prevention. Mol Nutr Food Res. 2013;57(11):1908-17. https://doi.org/1908-17. 10.1002/mnfr.201300040

13. Zhao J, Yan Q, Lu L, Zhang Y. In vivo antioxidant, hypoglycemic, and anti-tumor activities of anthocyanin extracts from purple sweet potato. Nutr Res Pract. 2013;7(5):359-65. https://doi.org/10.4162/nrp.2013.7.5.359

14. Yasa IWPS, Jawi IM, Mahendra AN. Ethanol extract of purple sweet potato tubers (Ipomea batatas L) decreases blood glucose and increase total antioxidant level in rats with high glucose intake. JUCMS. 2013;10(1-2):52-6. https://doi.org/10.17265/15486648\%2F2013.01.007

15. Mahadita GW, Jawi M, Suastika K. Purple sweet potato tuber extract lowers malondialdehyde and improves glycemic control in subjects with type 2 diabetes mellitus. Global Advanced Research Journal of Medicine and medical Sciences. 2016;5(7):208-13.

16. Jawi M, Artini GA, Mahendra AN, Suprapta DN. Purple sweet potato aqueous extract lowers blood pressure and prevents oxidative stress in hypertensive elderly patients at Nyuhkuning
Village, Mas, Ubud, Bali. Journal of Biology, Agriculture and Healthcare. 2014;4(21): 60-4.

17. Rauf R, Aini RN, Nurdiana. Pasting Characteristic of Composite Purple Sweet Potato and White Sweet Potato Flours. Journal of Nutraceuticals and Herbal Medicine. 2018;1(1):24-32. https://doi.org/10.23917/jnhm.v1i1.5738

18. Brown B, Roehl K, Betz M. Enteral nutrition formula selection: Current evidence and implications for practice. Nutr Clin Pract. 2015;30(1):72-85. https://doi.org/10.1177/0884533614561791

19. Knapp AW. Basic Algebra. Digital Second Editions. Published by the Author, East Setauket, New York. 2016.

20. AOAC. Official Methods of Analysis (18th edition). Association of Official Analytical, Chemists International, Maryland, USA. 2005.

21. Rauf R, Sarbini D. Pengaruh bahan penstabil terhadap sifat fisiko-kimia yoghurt yang dibuat dari tepung kedelai rendah lemak. Prosiding Seminar Nasional Biologi. 2012;9(1):484-9.

22. Stroud M, Duncan H, Nightingale J. Guidelines for Enteral Feeding in Adult Hospital Patients. Nutr Clin Pract. 2003;52(7):vii1-vii12. https://doi.org/10.1136/gut.52.suppl_7.vii1

23. Ambarsari I, Sarjana, Choliq A. Rekomendasi dalam penetapan standar mutu tepung ubi jalar. Jurnal Standarisasi. 2009;11(3): 212-9.

24. WHO. Codex General Standard for Soy Protein Products. 2019 (accessed: 2 October 2019)

Available from: http://www.fao.org/input/download/standards/.

25. Koswara S. Teknologi Pengolahan Umbi-Umbian Bagian 5: Pengolahan Ubi Jalar. Bogor: Institut Pertanian Bogor. 2016.

26. Rauf R, Zulaekah S, Widiyaningsih EN. Differences in cultivation areas and pretreatments in making purple sweet potato flours affect their antioxidant activities. International Journal of Pharmaceutical Research. 2019;11(SI1):585-93.

27. Liu F, Tang, CH. Emulsifying properties of soy protein nanoparticles: influence of the protein concentration and/or emulsification process. J Agric Food Chem. 2014;2:211-28. https://doi.org/10.1021/jf405348k

28. Wu DW, Chen X, Yang X, Leng ZX, Yan PS, Zhou, YM. Effect of heat treatment of soy protein isolate on the growth performance and immune function of broiler chickens. Poult Sci J. 2014;2:326-34. https://doi.org/10.3382/ps.2013-03507

29. Zadak Z, Kent-Smith L. Basics in clinical nutrition: Commercially prepared formulas. Clin Nutr ESPEN. 2009;4:e212-15.

30. Hassan-Ghomi M, Nikooyeh B, Motamed S, Neyestani TR. Efficacy of commercial formulas in 
comparison with home-made formulas for enteral feeding: A critical review. Medical Journal of the Islamic Republic of Iran. 2017;31:1-8. https://doi.org/10.14196/mjiri.31.55

31. Andarwulan N, Kusnandar F, Herawati D. Analisis Pangan. Jakarta: Penerbit Dian Rakyat. 2011.

32. Ichimaru S, Amagai T. Viscosity thickened enteral formula. Diet and Nutrition in Critical Care. 2015: 1463-77. https://doi.org/10.1007/978-1-4614-78362_27
33. Juszczak L, Galkowska D, Witczak T, Fortuna T. Effect of maltodextrins on the rheological properties of potato starch pastes and gels. Int $\mathbf{J}$ Food Sci. 2013;1-7

34. Ichimaru S, Amagai T, Wakita M, Shiro Y. Which is more effective to prevent enteral nutrition-related complications, high-or medium-viscosity thickened enteral formula in patients with percutaneous endoscopic gastronomy? A single center restropective chart review. Nutr Clin Prac. 2012;27(4):545-52. 